\title{
Origin of Cross-Over Phenomenon of Hysteresis Loops and High Absorption Loss Properties for Spinel Ferrite Nanoparticles
}

\author{
O. YALÇIN ${ }^{a, *}$, H. BAYRAKDAR ${ }^{b}$ AND S. ÖZÜM ${ }^{c}$ \\ ${ }^{a}$ Department of Physics, Niğde Ömer Halisdemir University, 51240 Niğde, Turkey \\ ${ }^{b}$ Department of Mechanical Engineering, Düzce University, 17100 Düzce, Turkey \\ ${ }^{c}$ Alaca Avni Celik Vocational School, Hitit University, 19600, Çorum, Turkey
}

Received: 29.06.2020 \& Accepted: 24.08.2020

Doi: 10.12693/APhysPolA.139.31 *e-mail: o.yalcin@ohu.edu.tr

\begin{abstract}
Spinel ferrite nanoparticles have been synthesized by the surfactant-assisted hydrothermal route using cetyltrimethylammonium bromide (CTAB) and ethylenediaminetetraacetic acid (EDTA) in the $\mathrm{NaOH}$ solution. Temperature evolution of magnetic hysteresis loops has been investigated in detail. The magnetic characterization of spinel nanoparticles has been measured by a quantum design vibrating sample magnetometer model 6000. The origin of a cross-over feature of ferrite nanoparticles has been observed at room temperature. Microwave properties of ferrites were investigated with the use of an Anritsu MS2028C VNA Master. The present studies also demonstrate that a microwave absorber can be fabricated within a ferrite polymer nanocomposite for technological applications up to $16 \mathrm{GHz}$, with the reflection loss of more than $-60 \mathrm{~dB}$ and $-50 \mathrm{~dB}$ by using CTAB and EDTA, respectively.

topics: cross-over phenomenon, ferrite nanoparticles, microwave and magnetic properties, magnetization
\end{abstract}

\section{Introduction}

Over the last few years, smart nanoparticles (NPs) have become the hotspot of basic research and applications mainly due to their interesting electronic and magnetic properties. Nanoparticle research is an essential part of our natural environment, high technology, medical and modern science [1-6]. NPs have also become a keyword for understanding the magnetism of very small magnetic structures [7-16]. Spinel ferrite NPs are particularly considered very attractive due to their unusual magnetic properties and their promising technological applications [17-21].Ferrites have generally been attracting the ever growing interest in fundamental science for a wide variety of their properties (e.g., optical, electrical and catalytic) and their thermal stability [22-48]. The ferrite NPs can be conventionally prepared by the hydrothermal method [49-52], sol-gel processing [53, 54], micro emulsion [55-57], chemical co-precipitation $[54,58,59]$, citrate precursor techniques [60], solvothermal [61], sonochemical reactions [62], ceramic technique [63], microwave synthesis $[64,65]$, etc. The magnetic properties of ferrite NPs have been investigated [66-75], however many properties of NPs should be examined in detail in finite nanosystems. To this end, the rich crystal chemistry in ferrite systems provides excellent opportunities to better understand the magnetic properties of NPs by chemical manipulations [76].

In the noteworthy part of this study, we have synthesized spinel ferrite $\left(\alpha-\mathrm{Fe}_{2} \mathrm{O}_{4}\right)$ NPs by using
CTAB-assisted and EDTA-assisted hydrothermal processes. Temperature evolution of magnetic hysteresis $(M-H)$ loops for ferrites has been investigated and their characteristic parameters $H_{s}$, $H_{c}, M_{s}$ and $M_{r}$ were determined. Surprisingly, crossover behaviour in $M-H$ loops at room temperature (RT) has been observed as the new property for spinel NPs. Such behaviour was first found for spinel NPs, however at a lower temperature $(\sim 50 \mathrm{~K})$. The crossover phenomenon widely attracts material scientists, physicists and chemists. Properties that appear in $M-H$ loops of ferrite NPs create opportunities for future applications in information storage, sensors and display devices.

The microwave absorbing measurements for spinel NPs were performed in this paper. We used a free-space method in the range from $8.2 \mathrm{GHz}$ to $18 \mathrm{GHz}$ at RT. A high absorption loss signal has been observed in the high-frequency regime.

\section{Experiments}

\subsection{Preparation of samples}

\subsubsection{Synthesis of spinel ferrite nanoparticles}

In this paper, spinel ferrite NPs were synthesized with the assistance of a cationic surfactant: 1-cetyltrimethylammonium bromide (CTAB) and of a chelating agent: 2-ethylenediaminetetraacetic acid (EDTA). 
In the experimental procedure by using method 1 $\alpha-\mathrm{Fe}_{2} \mathrm{O}_{4}$, ferrite NPs have been prepared using a surfactant-assisted (CTAB) hydrothermal process. According to this method, $0.003 \mathrm{~mol}$ surfactant CTAB was dissolved in $35 \mathrm{ml}$ deionized water to form a transparent solution. Then, ferric(III) chloride hexahydrate $\left(\mathrm{FeCl}_{3} \cdot 6 \mathrm{H}_{2} \mathrm{O}\right)$ of $0.004 \mathrm{~mol}$ was added to the solution and mixed for $10 \mathrm{~min}$. After stirring, a stoichiometric amount of $\alpha-\mathrm{Cl}_{2} 6 \mathrm{H}_{2} \mathrm{O}$ or $/$ and $\alpha-\mathrm{Cl}_{2} 6 \mathrm{H}_{2} \mathrm{O} \quad\left(\alpha-\mathrm{Cl}_{2}\right.$ salts $)$ was introduced into the mixed solution under vigorous stirring. Deionized water was added to make the solution for a total volume of $40 \mathrm{ml}$ and then $\mathrm{pH}$ of the solution mixture was adjusted to 11 . Before transferring to a teflon-lined autoclave of $50 \mathrm{ml}$ capacity, the solution mixture was pretreated under an ultrasonic water bath for $40 \mathrm{~min}$. A hydrothermal synthesis was carried out at $130^{\circ} \mathrm{C}$ for $15 \mathrm{~h}$ in an electric oven without shaking or stirring. Afterwards, the autoclave was gradually warmed up to RT. The collected black precipitate was several times washed with distilled water in an ultrasonic bath to remove any possible impurities. The solid was then heated

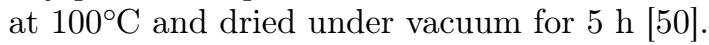

In the experimental procedure by using method 2 , $\alpha-\mathrm{Fe}_{2} \mathrm{O}_{4}$ spinel NPs have been synthesized by using a chelating agent-assisted (EDTA) hydrothermal process. The detailed procedure was the same as the synthesis of 1-NPs.

\subsubsection{Synthesis of ferrite polymer nanocomposites}

Spinel ferrite nanoparticles were inserted in polyacrylonitrile (PAN) to investigate the EM absorption properties. For this propose, ferrites (nanopowders) were dispersed in deionized water and stirred for $3 \mathrm{~h}$ at RT using a magnetic stirrer. Nanopowders and PAN are taken in the weight ratio of $3: x: 1$ ( $x$ is not disclosed) and thoroughly mixed with silver hexafluoroantimonate, which was used as the initiator for a polymerization process, in the glass bottle in the oven at $150^{\circ} \mathrm{C}$. The polymerization process took two days. After this period, the polymer was homogenized in a mortar and poured in the mould of a radius $r=400 \mathrm{~mm}$ and a thickness $c=2 \mathrm{~mm}$, and then left for $20 \mathrm{~min}$ at RT. The magnetic parameters $\left(H_{c}, H_{s}, M_{s}, M_{r}\right)$ obtained from the curves $H$ are shown in Table I.

\subsection{Measurements of ferrite nanoparticles}

The magnetic hysteresis loops $(M-H)$ of spinel NPs have been measured by a quantum design vibrating sample magnetometer (VSM) model 6000 . The microwave properties of ferrites were investigated using an Anritsu MS2028C VNA Master. The measurement of NPs was done with a Malvern Instruments Zetasizer Nano-ZS. In turn, the microwave absorbing measurements were made using the free space method which is an important wave transmission scheme in communication and materials research (e.g., in radar and satellite
Characteristic magnetic parameters

for each composition at $50 \mathrm{~K}$.

\begin{tabular}{|c|c|c|c|c|c|}
\hline & Sample & $\begin{array}{l}H_{c} \\
{[\mathrm{G}]}\end{array}$ & $\begin{array}{l}H_{s} \\
{[\mathrm{G}]}\end{array}$ & $\begin{array}{c}M_{s} \\
{[\mathrm{emu} / \mathrm{g}]}\end{array}$ & $\begin{array}{c}M_{r} \\
{[\mathrm{emu} / \mathrm{g}]}\end{array}$ \\
\hline \multirow{5}{*}{ e } & $\mathrm{CrFe}_{2} \mathrm{O}_{4}$ & 175.58 & 12819 & 0.1291 & 0.058 \\
\hline & $\mathrm{Mn}_{0.5} \mathrm{Co}_{0.5} \mathrm{Fe}_{2} \mathrm{O}_{4}$ & 4025.5 & 15905.61 & 0.174 & 0.13 \\
\hline & $\mathrm{Mn}_{0.5} \mathrm{Cr}_{0.5} \mathrm{Fe}_{2} \mathrm{O}_{4}$ & 0 & 23905 & 0.046 & 0.029 \\
\hline & $\mathrm{Ni}_{0.5} \mathrm{Cr}_{0.5} \mathrm{Fe}_{2} \mathrm{O}_{4}$ & 225.33 & 24413 & 0.052 & 0.021 \\
\hline & $\mathrm{Co}_{0.5} \mathrm{Cr}_{0.5} \mathrm{Fe}_{2} \mathrm{O}_{4}$ & 5058.5 & 49697 & 0.261 & 0.098 \\
\hline \multirow{5}{*}{ 穴 } & $\mathrm{CrFe}_{2} \mathrm{O}_{4}$ & 210.04 & 23851 & 0.0142 & 0.0068 \\
\hline & $\mathrm{Mn}_{0.5} \mathrm{Co}_{0.5} \mathrm{Fe}_{2} \mathrm{O}_{4}$ & 11237 & 23361 & 0.417 & 0.33461 \\
\hline & $\mathrm{Mn}_{0.5} \mathrm{Cr}_{0.5} \mathrm{Fe}_{2} \mathrm{O}_{4}$ & 93.64 & 9008.46 & 0.2224 & 0.1648 \\
\hline & $\mathrm{Ni}_{0.5} \mathrm{Cr}_{0.5} \mathrm{Fe}_{2} \mathrm{O}_{4}$ & 0 & 9806.52 & 0.0211 & 0.0084 \\
\hline & $\mathrm{Co}_{0.5} \mathrm{Cr}_{0.5} \mathrm{Fe}_{2} \mathrm{O}_{4}$ & 11220 & 40568 & 0.2507 & 0.1707 \\
\hline
\end{tabular}

communication EM waves propagate through free space). In recent years, an increasing interest in using the free space techniques was observed for the measurement of EM properties of materials. Since microwave antennas have far-field focusing ability, it is possible to make accurate free space measurements at microwave frequencies $[51,52,77-83]$.

\section{Results and discussion}

Figure 1 shows the magnetic hysteresis curves of $\mathrm{Mn}_{0.5} \mathrm{Co}_{0.5} \mathrm{Fe}_{2} \mathrm{O}_{4}$ (black line) $/ \mathrm{Cu}_{0.5} \mathrm{Zn}_{0.5} \mathrm{Fe}_{2} \mathrm{O}_{4}$ (red line) spinel type ferrite NPs for selected temperatures and the characteristic parameter values, i.e., $H_{c}, H_{s}, M_{s}$ and $M_{r}$. The hysteresis loops obtained with CTAB and EDTA are nearly symmetric at given temperature in relation to the case of the zero magnetic fields. The FM properties have been observed for all samples. One can notice that the values of $H_{c}$ with CTAB (see Fig. 1a) increase for both spinel ferrite NPs when temperature decreases starting from RT to $10 \mathrm{~K}$. In turn, the values of $H_{c}$ obtained with EDTA for $\mathrm{Mn}_{0.5} \mathrm{Co}_{0.5} \mathrm{Fe}_{2} \mathrm{O}_{4}$ (black line) decrease as temperature increases (see Fig. 1b), whereas for $\mathrm{Cu}_{0.5} \mathrm{Zn}_{0.5} \mathrm{Fe}_{2} \mathrm{O}_{4}$ (see inset of Fig. 1b) the $H_{c}$ values initially increase with increasing temperature and further decrease. In the case of $\mathrm{Mn}_{0.5} \mathrm{Co}_{0.5} \mathrm{Fe}_{2} \mathrm{O}_{4}$, an exponential increase of $H_{c}$ and $H_{s}$ can be observed in Fig. 1 when temperature decreases, therefore changing, respectively, in the range $\quad 0.165-7.777 \mathrm{kG} \quad$ (CTAB) $/ 0.76-13.45 \mathrm{kG}$ (EDTA) and in the range $10.05-21.37 \mathrm{kG}$ $(\mathrm{CTAB}) / 13.90-27.14 \mathrm{kG} \quad$ (EDTA). Comparing the $H_{c}$ values for $\mathrm{Mn}_{0.5} \mathrm{Co}_{0.5} \mathrm{Fe}_{2} \mathrm{O}_{4}$ ferrite NPs obtained using CTAB/EDTA, the $H_{c}$ values for $\mathrm{Cu}_{0.5} \mathrm{Zn}_{0.5} \mathrm{Fe}_{2} \mathrm{O}_{4}$ in the range $0.068-0.216 \mathrm{kG}$ $(\mathrm{CTAB}) / 0.103-0.125 \mathrm{kG}$ (EDTA/inset) are considered small. After $H_{c}$ of $\mathrm{Cu}_{0.5} \mathrm{Zn}_{0.5} \mathrm{Fe}_{2} \mathrm{O}_{4}$ ferrites reaches its maximum (red line, inset Fig. 1b), it decreases logarithmically with increasing temperature. In fact, this maximum at temperature $\sim 49.91 \mathrm{~K}$ originated from nonmagnetic $\mathrm{Zn}$ ions and the spin-flop (SF) transition [15]. 

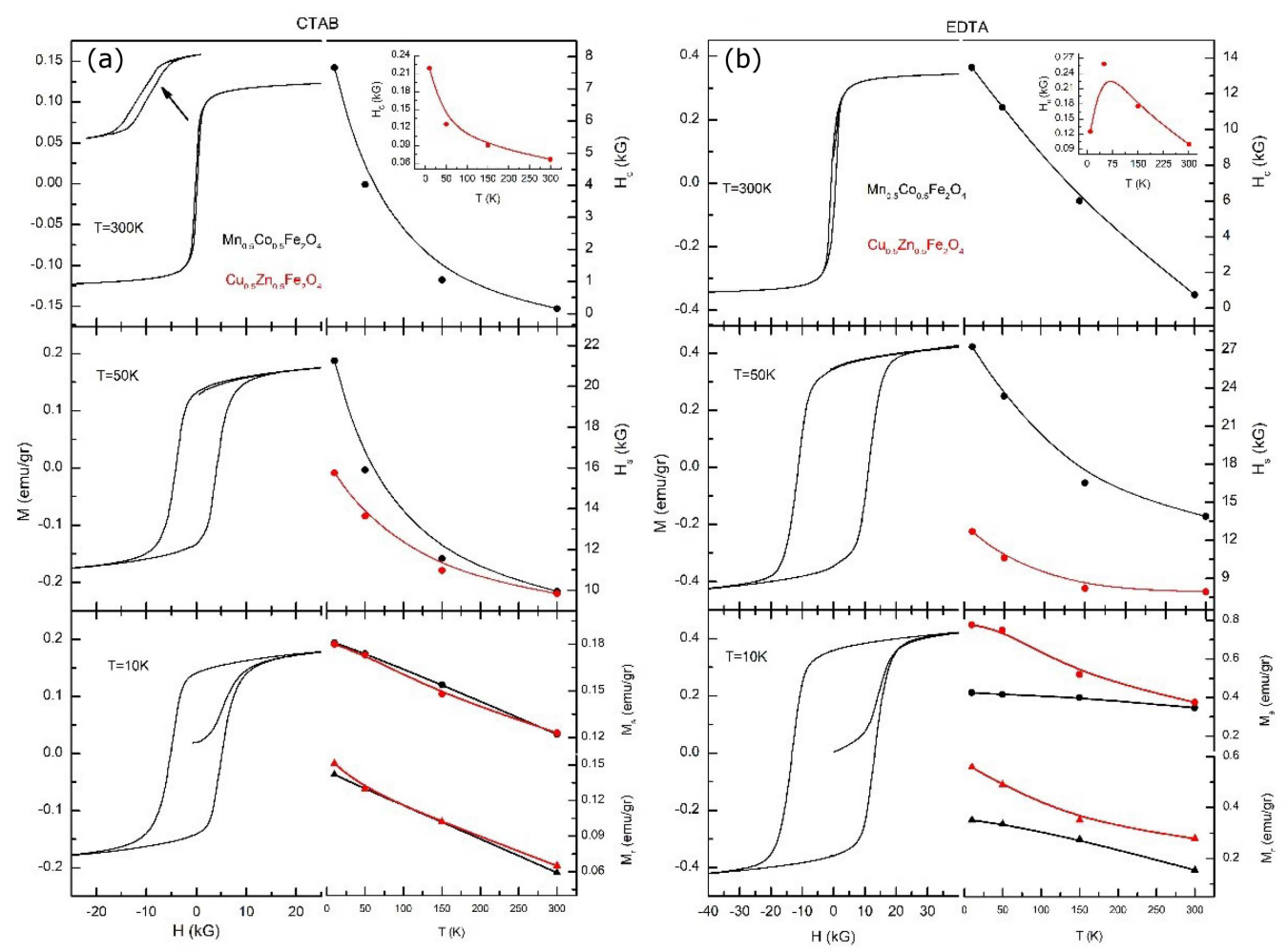

Fig. 1. Magnetic field evolution of magnetization for $\mathrm{Mn}_{0.5} \mathrm{Co}_{0.5} \mathrm{Fe}_{2} \mathrm{O}_{4}$ (black line) $/ \mathrm{Cu}_{0.5} \mathrm{Zn}_{0.5} \mathrm{Fe}_{2} \mathrm{O}_{4}$ (red line) spinel ferrite NPs by using (a) CTAB and (b) EDTA in the left-hand column. $H_{c}, H_{s}, M_{s}$ and $M_{r}$ versus temperature in the right-hand column.

To sum up this part, one can notice in Fig. 1b that for both investigated samples, the values of $H_{s}, M_{s}$ and $M_{r}$ increase with the decreasing temperature when using CTAB and EDTA. In the case of $H_{s}$, it strongly depends on the applied magnetic field $H_{c}$. In turn, $M_{s}$ and $M_{r}$ have shown for both ferrites a nearly linear dependence on temperature, regardless of the method used.

In Fig. 2, we have presented the $M-H$ loops at given temperatures for $\mathrm{Mn}_{0.5} \mathrm{Cr}_{0.5} \mathrm{Fe}_{2} \mathrm{O}_{4}$ (black line), $\mathrm{Ni}_{0.5} \mathrm{Cr}_{0.5} \mathrm{Fe}_{2} \mathrm{O}_{4}$ (red line) spinel ferrite NPs and $\mathrm{CrFe}_{2} \mathrm{O}_{4}$ NPs (blue line). The $M-H$ loops for $\mathrm{Mn}_{0.5} \mathrm{Cr}_{0.5} \mathrm{Fe}_{2} \mathrm{O}_{4}$ and $\mathrm{Ni}_{0.5} \mathrm{Cr}_{0.5} \mathrm{Fe}_{2} \mathrm{O}_{4}$ NPs by using $\mathrm{CTAB}$ show the $\mathrm{FM}$ behaviour at $10 \mathrm{~K}$ and the SP behaviour at RT in Fig. 2a. Relying on EDTA results (see Fig. 2b), the SP behaviour in general has been seen for $\mathrm{Ni}_{0.5} \mathrm{Cr}_{0.5} \mathrm{Fe}_{2} \mathrm{O}_{4}$. Moreover, there is no evidence of coercive fields for $\mathrm{Mn}_{0.5} \mathrm{Cr}_{0.5} \mathrm{Fe}_{2} \mathrm{O}_{4} \mathrm{NPs}$ when using CTAB at $50 \mathrm{~K}$ and $300 \mathrm{~K}$, and also for $\mathrm{CrFe}_{2} \mathrm{O}_{4}$ NPs when using EDTA at $50 \mathrm{~K}$. The important characteristic observed in the $M-H$ loop for $\mathrm{Mn}_{0.5} \mathrm{Cr}_{0.5} \mathrm{Fe}_{2} \mathrm{O}_{4}$ and $\mathrm{Ni}_{0.5} \mathrm{Cr}_{0.5} \mathrm{Fe}_{2} \mathrm{O}_{4}$ NPs by using CTAB at $50 \mathrm{~K}$ is, in fact, the appearance of crossover for $M_{r}$ (of 0.029 and $0.021 \mathrm{emu} / \mathrm{g}$, respectively) and for $M_{s}$ (of 0.046 and $0.052 \mathrm{emu} / \mathrm{g}$, respectively), as indicated Fig. 2a. The evolution of $H_{c}, H_{s}, M_{s}$ and $M_{r}$ with temperature for $\mathrm{Mn}_{0.5} \mathrm{Cr}_{0.5} \mathrm{Fe}_{2} \mathrm{O}_{4}$ and $\mathrm{Ni}_{0.5} \mathrm{Cr}_{0.5} \mathrm{Fe}_{2} \mathrm{O}_{4}$ NPs has been investigated and shown in detail on the right side of Fig. 3a and b. This crossover property likely comes from the higher magnetocrystalline anisotropy at a positive external magnetic field. It is known that NPs can easily be thermally activated and overcome magnetic anisotropy. The magnetocrystalline anisotropy essentially arises from the spin-orbit $(\mathrm{L}-\mathrm{S})$ coupling but to a lesser extent also from dipolar interactions. This property has also been observed for $\mathrm{CrFe}_{2} \mathrm{O}_{4}$ NPs (blue line) by using EDTA in Fig. $2 b$.

The dependence of magnetization as a function of the external magnetic field through the $M-H$ loop for $\mathrm{Co}_{0.5} \mathrm{Cr}_{0.5} \mathrm{Fe}_{2} \mathrm{O}_{4}$ (black) ferrite NPs by using CTAB/EDTA has been displayed on the left side of Fig. 3a and b. Based on these results, we determined the characteristics of $H_{c}, H_{s}$, $M_{s}$ and $M_{r}$ for the following spinel ferrite NPs, namely $\mathrm{Co}_{0.5} \mathrm{Cr}_{0.5} \mathrm{Fe}_{2} \mathrm{O}_{4}$ (black), $\mathrm{Mn}_{0.5} \mathrm{Cr}_{0.5} \mathrm{Fe}_{2} \mathrm{O}_{4}$ (purple), $\mathrm{Ni}_{0.5} \mathrm{Cr}_{0.5} \mathrm{Fe}_{2} \mathrm{O}_{4}$ (cyan), $\mathrm{Cu}_{0.5} \mathrm{Cr}_{0.5} \mathrm{Fe}_{2} \mathrm{O}_{4}$ (green), $\mathrm{Zn}_{0.5} \mathrm{Cr}_{0.5} \mathrm{Fe}_{2} \mathrm{O}_{4}$ (blue) and $\mathrm{CrFe}_{2} \mathrm{O}_{4}$ (red), which are shown on the right side in Fig. $3 \mathrm{a}$ and $\mathrm{b}$. It is clear that in general the $M-H$ curves are symmetric from $10 \mathrm{~K}$ to $\mathrm{RT}$ with respect to the magnetic field values. For the investigated samples, their hysteresis illustrated the FM behaviour at RT. For all NPs, $H_{c}$ obtained with CTAB increases with the decreasing temperature, see Fig. 3a. It can also be seen that for $\mathrm{Co}_{0.5} \mathrm{Cr}_{0.5} \mathrm{Fe}_{2} \mathrm{O}_{4}$ (black) ferrites, the values of $H_{c}$ are bigger than those for the other NPs, when using CTAB and EDTA. In the case of $\mathrm{Ni}_{0.5} \mathrm{Cr}_{0.5} \mathrm{Fe}_{2} \mathrm{O}_{4}$ (cyan) ferrite using EDTA, its $H_{c}$ values remain constant for all temperatures. In the case of $\mathrm{Cu}_{0.5} \mathrm{Cr}_{0.5} \mathrm{Fe}_{2} \mathrm{O}_{4}$ and $\mathrm{CrFe}_{2} \mathrm{O}_{4} \mathrm{NPs}$, 

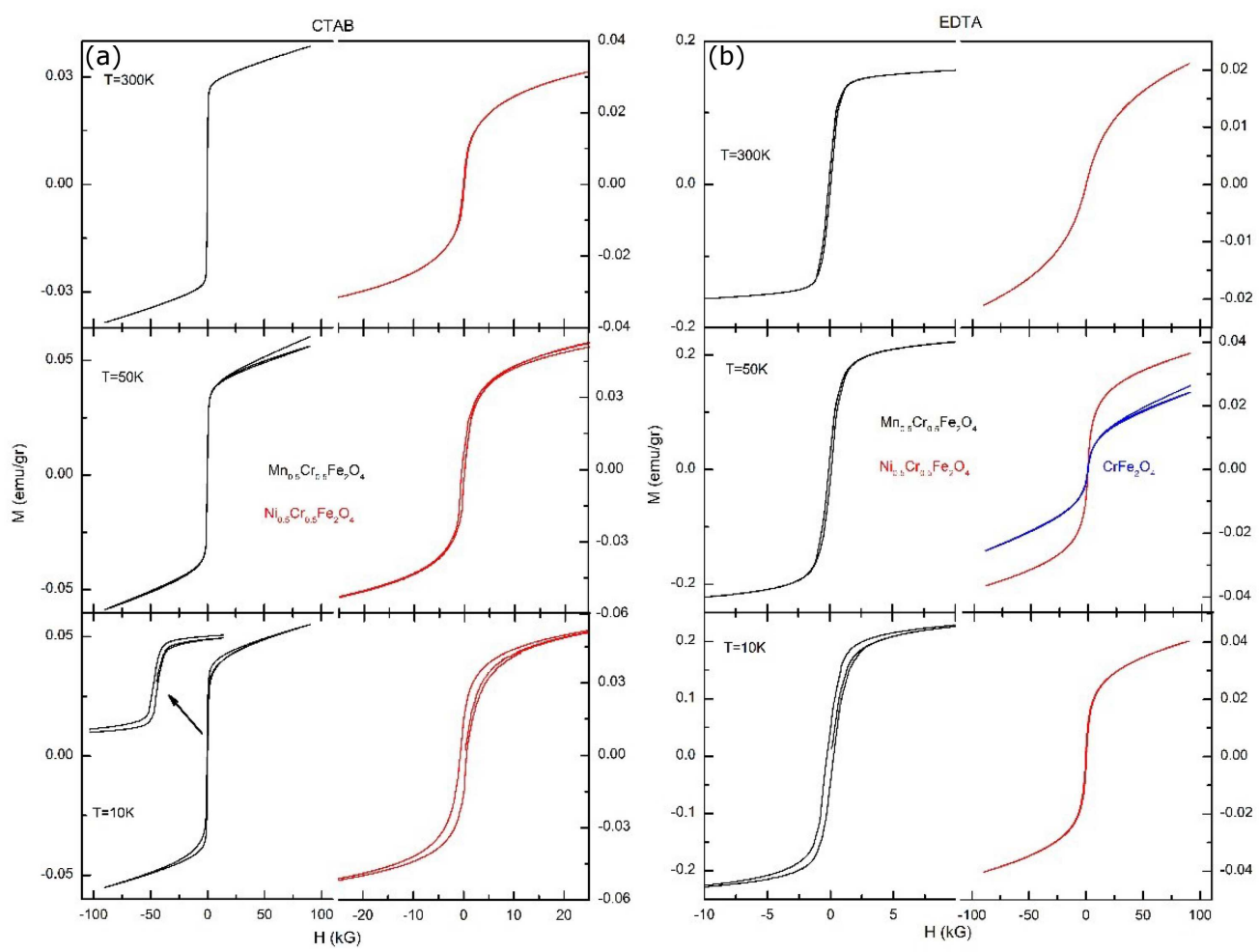

Fig. 2. Magnetic field evolution of magnetization for $\mathrm{Mn}_{0.5} \mathrm{Cr}_{0.5} \mathrm{Fe}_{2} \mathrm{O}_{4}$ (black line), $\mathrm{Ni}_{0.5} \mathrm{Cr}_{0.5} \mathrm{Fe}_{2} \mathrm{O}_{4}$ (red line) spinel ferrite NPs by using (a) CTAB and (b) EDTA and $\mathrm{CrFe}_{2} \mathrm{O}_{4}$ (blue line) spinel type ferrite NPs by using EDTA.
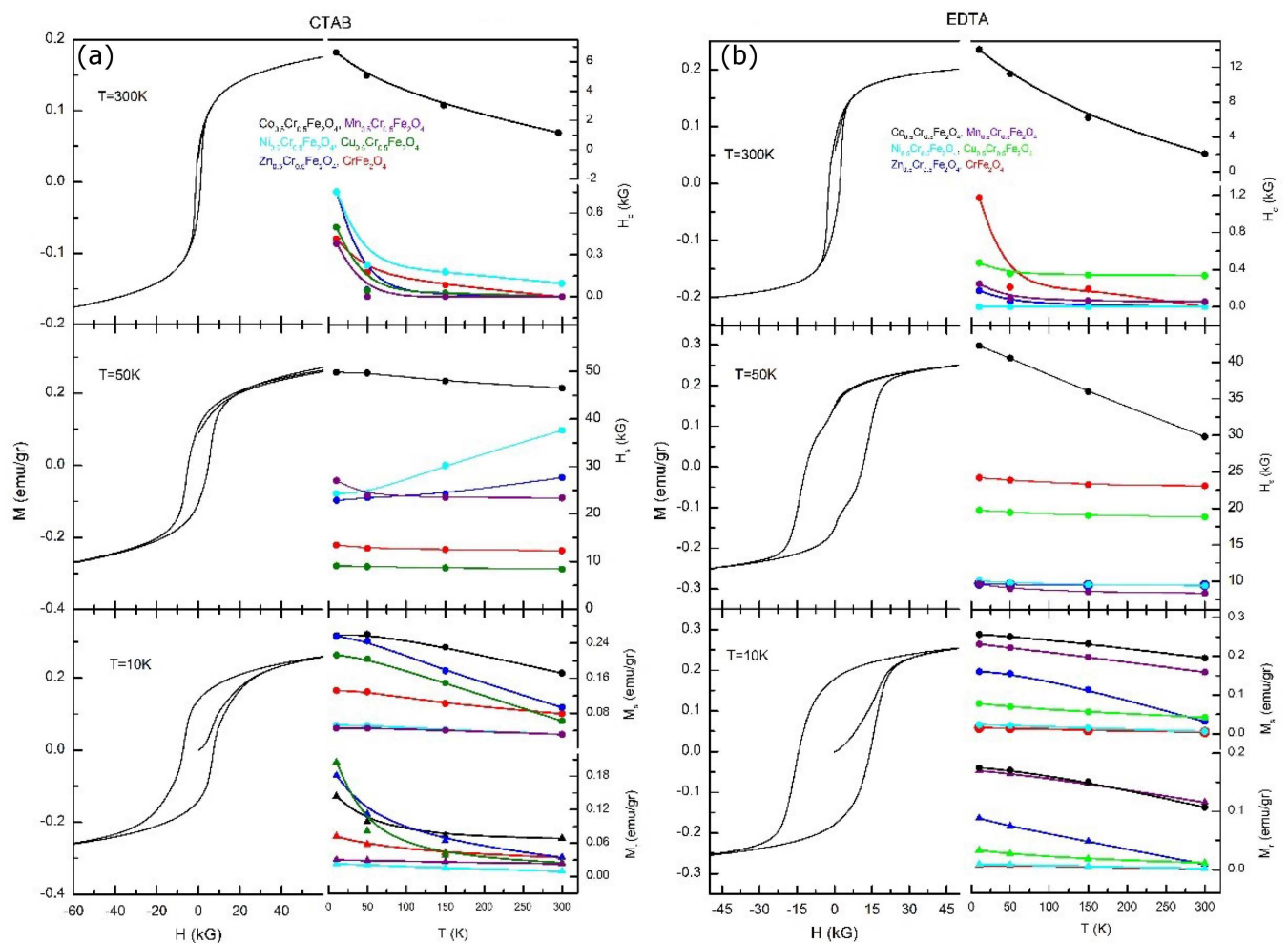

Fig. 3. Magnetic field evolution of magnetization for $\mathrm{Co}_{0.5} \mathrm{Cr}_{0.5} \mathrm{Fe}_{2} \mathrm{O}_{4}$ (black line) spinel type ferrite NPs by using (a) CTAB and (b) EDTA in the left-hand column. $H_{c}, H_{s}, M_{s}$ and $M_{r}$ of $\mathrm{Co}_{0.5} \mathrm{Cr}_{0.5} \mathrm{Fe}_{2} \mathrm{O}_{4}$, $\mathrm{Mn}_{0.5} \mathrm{Cr}_{0.5} \mathrm{Fe}_{2} \mathrm{O}_{4}, \mathrm{Ni}_{0.5} \mathrm{Cr}_{0.5} \mathrm{Fe}_{2} \mathrm{O}_{4}, \mathrm{Cu}_{0.5} \mathrm{Cr}_{0.5} \mathrm{Fe}_{2} \mathrm{O}_{4}, \mathrm{Zn}_{0.5} \mathrm{Cr}_{0.5} \mathrm{Fe}_{2} \mathrm{O}_{4}$ and $\mathrm{CrFe}_{2} \mathrm{O}_{4}$ spinel type ferrite NPs by using (a) CTAB and (b) EDTA versus temperature in the right-hand column. 

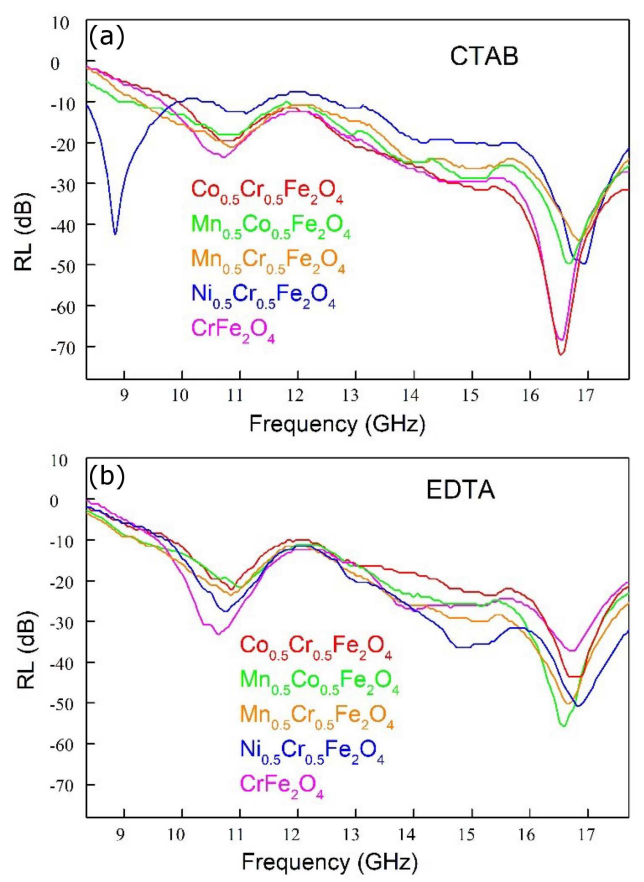

Fig. 4. Absorption spectra of $\mathrm{Co}_{0.5} \mathrm{Cr}_{0.5} \mathrm{Fe}_{2} \mathrm{O}_{4}+$ polyacrylonitrile nanocomposite (red line), $\mathrm{Mn}_{0.5} \mathrm{Co}_{0.5} \mathrm{Fe}_{2} \mathrm{O}_{4}+$ polyacrylonitrile nanocomposite (green line), $\quad \mathrm{Mn}_{0.5} \mathrm{Cr}_{0.5} \mathrm{Fe}_{2} \mathrm{O}_{4}+$ polyacrylonitrile nanocomposite (orange line), $\mathrm{Ni}_{0.5} \mathrm{Cr}_{0.5} \mathrm{Fe}_{2} \mathrm{O}_{4}+$ polyacrylonitrile nanocomposite (blue line) and $\mathrm{CrFe}_{2} \mathrm{O}_{4}+$ polyacrylonitrile nanocomposite (pink line) NPs by using (a) CTAB and (b) EDTA.

the results of $H_{s}$ obtained with CTAB and EDTA remain constant, while for $\mathrm{Mn}_{0.5} \mathrm{Cr}_{0.5} \mathrm{Fe}_{2} \mathrm{O}_{4}$ and $\mathrm{Ni}_{0.5} \mathrm{Cr}_{0.5} \mathrm{Fe}_{2} \mathrm{O}_{4}, H_{s}$ using EDTA is constant up to $50 \mathrm{~K}$, except at a very low temperature. What is more, $H_{s}$ decreases for $\mathrm{Co}_{0.5} \mathrm{Cr}_{0.5} \mathrm{Fe}_{2} \mathrm{O}_{4}$ (CTAB/EDTA) and $\mathrm{Mn}_{0.5} \mathrm{Cr}_{0.5} \mathrm{Fe}_{2} \mathrm{O}_{4}$ (CTAB), whereas for $\mathrm{Ni}_{0.5} \mathrm{Cr}_{0.5} \mathrm{Fe}_{2} \mathrm{O}_{4}$ (CTAB) and $\mathrm{Zn}_{0.5} \mathrm{Cr}_{0.5} \mathrm{Fe}_{2} \mathrm{O}_{4}(\mathrm{CTAB})$ it increases with the increasing temperature. Further, the depicted $M_{s}$ results with CTAB for $\mathrm{Co}_{0.5} \mathrm{Cr}_{0.5} \mathrm{Fe}_{2} \mathrm{O}_{4}$ and $\mathrm{Zn}_{0.5} \mathrm{Cr}_{0.5} \mathrm{Fe}_{2} \mathrm{O}_{4}$ ferrite NPs increase logarithmically with the decreasing temperature in Fig. 3a.

Moreover, $M_{s}$ of $\mathrm{Cu}_{0.5} \mathrm{Cr}_{0.5} \mathrm{Fe}_{2} \mathrm{O}_{4}$ and $\mathrm{CrFe}_{2} \mathrm{O}_{4}$ samples, when CTAB is used, display a nearly linear increase, whereas $M_{s}$ of $\mathrm{Mn}_{0.5} \mathrm{Cr}_{0.5} \mathrm{Fe}_{2} \mathrm{O}_{4}$ and $\mathrm{Ni}_{0.5} \mathrm{Cr}_{0.5} \mathrm{Fe}_{2} \mathrm{O}_{4}$ NPs does not show any obvious dependence on temperature and remains constant (see Fig. 3a). Further, $M_{s}$ for $\mathrm{Co}_{0.5} \mathrm{Cr}_{0.5} \mathrm{Fe}_{2} \mathrm{O}_{4}$, $\mathrm{Mn}_{0.5} \mathrm{Cr}_{0.5} \mathrm{Fe}_{2} \mathrm{O}_{4}$ and $\mathrm{Zn}_{0.5} \mathrm{Cr}_{0.5} \mathrm{Fe}_{2} \mathrm{O}_{4}$ spinel NPs exhibits a linear increase, while $M_{s}$ of $\mathrm{Ni}_{0.5} \mathrm{Cr}_{0.5} \mathrm{Fe}_{2} \mathrm{O}_{4}, \quad \mathrm{Cu}_{0.5} \mathrm{Cr}_{0.5} \mathrm{Fe}_{2} \mathrm{O}_{4}$ and $\mathrm{CrFe}_{2} \mathrm{O}_{4}$ samples, when EDTA is used, remains constant (see Fig. 3b). Further on, $M_{r}$ of $\mathrm{Co}_{0.5} \mathrm{Cr}_{0.5} \mathrm{Fe}_{2} \mathrm{O}_{4}$, $\mathrm{Cu}_{0.5} \mathrm{Cr}_{0.5} \mathrm{Fe}_{2} \mathrm{O}_{4}$ and $\mathrm{Zn}_{0.5} \mathrm{Cr}_{0.5} \mathrm{Fe}_{2} \mathrm{O}_{4}$ samples, when CTAB is used, shows an exponential decrease with the increasing temperature in Fig. 3a. It can be deduced, however, that $M_{r}$ of $\mathrm{Mn}_{0.5} \mathrm{Cr}_{0.5} \mathrm{Fe}_{2} \mathrm{O}_{4}$,
$\mathrm{Ni}_{0.5} \mathrm{Cr}_{0.5} \mathrm{Fe}_{2} \mathrm{O}_{4}$ and $\mathrm{CrFe}_{2} \mathrm{O}_{4}$ samples by using CTAB is not obviously dependent on temperature. In turn, $M_{r}$ for $\mathrm{Co}_{0.5} \mathrm{Cr}_{0.5} \mathrm{Fe}_{2} \mathrm{O}_{4}, \mathrm{Mn}_{0.5} \mathrm{Cr}_{0.5} \mathrm{Fe}_{2} \mathrm{O}_{4}$ and $\mathrm{Zn}_{0.5} \mathrm{Cr}_{0.5} \mathrm{Fe}_{2} \mathrm{O}_{4}$ samples by using EDTA can be treated as a linear growth with the decreasing temperature in Fig. 3b. The calculations performed with EDTA indicate that $M_{r}$ of $\mathrm{Cu}_{0.5} \mathrm{Cr}_{0.5} \mathrm{Fe}_{2} \mathrm{O}_{4}$, $\mathrm{Ni}_{0.5} \mathrm{Cr}_{0.5} \mathrm{Fe}_{2} \mathrm{O}_{4}$ and $\mathrm{CrFe}_{2} \mathrm{O}_{4}$ samples remains nearly constant on temperature.

Further on, Fig. 4 demonstrates the measured EM absorption spectra for $\mathrm{Co}_{0.5} \mathrm{Cr}_{0.5} \mathrm{Fe}_{2} \mathrm{O}_{4}$ (red), $\mathrm{Mn}_{0.5} \mathrm{Co}_{0.5} \mathrm{Fe}_{2} \mathrm{O}_{4}$ (green), $\mathrm{Mn}_{0.5} \mathrm{Cr}_{0.5} \mathrm{Fe}_{2} \mathrm{O}_{4}$ (orange), $\mathrm{Ni}_{0.5} \mathrm{Cr}_{0.5} \mathrm{Fe}_{2} \mathrm{O}_{4}$ (blue) and $\mathrm{CrFe}_{2} \mathrm{O}_{4}$ (pink) spinel ferrite-polymer (NPs/PAN) nanocomposites by using (a) CTAB and (b) EDTA. The relationship between the microwave frequency and the reflection loss was measured in the range of $8.2-18 \mathrm{GHz}$. The reflection loss of $\mathrm{Mn}_{0.5} \mathrm{Co}_{0.5} \mathrm{Fe}_{2} \mathrm{O}_{4}$ (green), $\mathrm{Mn}_{0.5} \mathrm{Cr}_{0.5} \mathrm{Fe}_{2} \mathrm{O}_{4}$ (orange) and $\mathrm{Ni}_{0.5} \mathrm{Cr}_{0.5} \mathrm{Fe}_{2} \mathrm{O}_{4}$ (blue) spinel ferrite-polymer nanocomposites by using CTAB is rather low for all the frequencies between 8.2 and $18 \mathrm{GHz}$ and the peak values are around $-40 \mathrm{~dB}$. The maximum reflection loss reaches $-70 \mathrm{~dB}$ at the matching frequency of 16.6 GHz, when using CTAB (see Fig. 4a), whereas when using EDTA (see Fig. 4b), it reaches the value of $-50 \mathrm{~dB}$ at $16.8 \mathrm{GHz}$. Such high absorption loss peaks indicate an attractive potential for microwave applications [84-88].

\section{Conclusion}

The spinel ferrite NPs have been synthesized by the surfactant-assisted hydrothermal route applying CTAB and EDTA, by using the $\mathrm{NaOH}$ solution at room temperature. The crossover properties with hysteresis loops centred at $50 \mathrm{~K}$ are especially seen in $\mathrm{Cr}$ doped samples $\left(\mathrm{CrFe}_{2} \mathrm{O}_{4}, \mathrm{Mn}_{0.5} \mathrm{Cr}_{0.5} \mathrm{Fe}_{2} \mathrm{O}_{4}\right.$, $\left.\mathrm{Ni}_{0.5} \mathrm{Cr}_{0.5} \mathrm{Fe}_{2} \mathrm{O}_{4}, \mathrm{Co}_{0.5} \mathrm{Cr}_{0.5} \mathrm{Fe}_{2} \mathrm{O}_{4}\right)$. Such a surprising behaviour makes the spinel ferrite NPs desirable for technological and/or biomedical applications. One of the most important parameters in hysteresis loops is $H_{c}$ which is related to the magnetic anisotropy, saturation magnetization and particle size. In general, the samples exhibiting these crossover properties have low coercivity except for $\mathrm{Co}_{0.5} \mathrm{Cr}_{0.5} \mathrm{Fe}_{2} \mathrm{O}_{4}$ NPs by using CTAB. A large value of coercivity of $\mathrm{Co}_{0.5} \mathrm{Cr}_{0.5} \mathrm{Fe}_{2} \mathrm{O}_{4} \mathrm{NPs}$ by using CTAB at $50 \mathrm{~K}$ is likely due to its higher magnetocrystalline anisotropy of $\mathrm{Co}^{2+}$ ions beginning to occupy the octahedral site due to its important spin-orbit (L-S) coupling. Also, $\mathrm{Co}_{0.5} \mathrm{Cr}_{0.5} \mathrm{Fe}_{2} \mathrm{O}_{4}$ NPs by using CTAB have the highest saturation magnetization when compared to the other spinel ferrite NPs with the shown crossover phenomenon. The behaviour of coercivity in the spinel ferrite NPs could be explained based on Brown's relation $[47,89,90]$ expressed as

$$
H_{c}=0.96 \frac{K}{M_{s}},
$$


where $K$ is the anisotropy constant. From the hysteresis loops with crossover properties, the remanence ratio $R=M_{r} / M_{s}$ is calculated. Importantly, this ratio can be treated as an indicator for the presence of the intergrain exchanges [91]. It was reported that for $R=0.5$, randomly oriented non-interacting NPs undergo coherent rotations. If $R<0.5$, one sees the NPs with magnetostatic interactions. The exchangecoupled interaction exists when $R>0.5$ [63]. The values of $M_{r} / M_{s}$ of $\mathrm{CrFe}_{2} \mathrm{O}_{4}, \mathrm{Ni}_{0.5} \mathrm{Cr}_{0.5} \mathrm{Fe}_{2} \mathrm{O}_{4}$, $\mathrm{Co}_{0.5} \mathrm{Cr}_{0.5} \mathrm{Fe}_{2} \mathrm{O}_{4}$ NPs are lower than 0.5, except for $\mathrm{Mn}_{0.5} \mathrm{Cr}_{0.5} \mathrm{Fe}_{2} \mathrm{O}_{4}$ NPs. Thus, the magnetostatic interaction is dominant for these ferrites. In the case of the exchange-coupled interaction, it is dominant for $\mathrm{Mn}_{0.5} \mathrm{Cr}_{0.5} \mathrm{Fe}_{2} \mathrm{O}_{4}$ NPs [38]. Furthermore, the $\mathrm{L}-\mathrm{S}$ coupling, the exchange-coupled interaction, the magnetostatic interaction and the intergrain exchange for NPs were responsible for the magnetocrystalline anisotropy. If the $\mathrm{L}-\mathrm{S}$ coupling prefers the spin and the orbit to be parallel to each other, the total magnetic moment will only be larger than a part of the spinel side and consequently the $g$-factor will be $>2$. One can see then that the origin of the crossover phenomenon is attributed to the magnetocrystalline anisotropy for spinel NPs. Experimentalists also investigated the EM absorption properties of these materials at $8.2-18 \mathrm{GHz}$. In addition, the ferrite-polymer (NPs/PAN) nanocomposites exhibited good EM absorption properties. Nanocomposites showed a higher EM absorption frequency and wider absorption bandwidth $(R L<-20 \mathrm{~dB})$ due to the larger magnetic anisotropy of ferrite NPs. Our studies suggest that ferrite-polymer nanocomposites can be used as a good EM absorption material in the $8-20 \mathrm{GHz}$ range.

The spinel ferrite nanoparticles are used in wastewater treatment, magnetic recording media, radiofrequency coil fabrication, transformer cores, biosensors, microwave devices, solutions to many environmental problems, industrial and medical applications. One of the superior properties of spinel ferrites is that they can be easily recycled by applying an external magnetic field due to their appropriate magnetic properties. Moreover, to change the dielectric, magnetic and microwave properties of these ferrite nanoparticles, doping of other metal ions can also be performed. What is more, nanoparticles need to be coated with suitable biological organic molecules to increase their biocompatibility.

\section{Acknowledgments}

The authors are grateful to the Scientific and Technological Research Council of Turkey (TUBİTAK, Contract No. 112E044) and the Scientific Research Projects Unit of Niğde University (Grant no. FEB2015/02-DOKTEP) for financially supporting this study.

\section{References}

[1] O. Yalçın, Nanorods, in: Nanotechnology and Nanomaterials, InTech, 2012.

[2] J. Wang, Q.W. Chen, C. Zeng, B.Y. Hou, Adv. Mater. 16, 137 (2004).

[3] K. Donaldson, V. Stone, C.L. Tran, W. Kreyling, P.J. Borm, Occup. Environ. Med. 61, 727 (2004).

[4] W.-T. Liu, J. Biosci. Bioeng. 102, 1 (2006).

[5] M.C. Roco, National Nanotechnology Initiative - Past, Present, Future. Handbook on Nanoscience, Engineering, and Technology, 2nd ed., 2007, p. 1.

[6] A.-H. Lu, E.L. Salabas, F. Schüth, Angew. Chem. Int. Ed. Engl. 46, 1222 (2007).

[7] S.H. Al-Heniti, A. Umar, H.M. Zaki, G.N. Dar, A.A. Al-Ghamdi, S.H. Kim, J. Nanosci. Nanotechnol. 14, 3765 (2014).

[8] S. Ravi, A. Karthikeyan, N.A. Nesakumari, K.S. Pugazhvadivu, K. Tamilarasan, Curr. Appl. Phys. 14, 259 (2014).

[9] J. Panda, T.K. Nath, AIP Conf. Proc. 1512, 1120 (2013).

[10] M. Faham, H. Shokrollahi, G. Yousefi, S. Abbasi, Adv. Mater. Res. 829, 274 (2013).

[11] S.S.P. Parkin, M. Hayashi, L. Thomas, Science 320, 190 (2008).

[12] B. Sunkara, R.D.K. Misra, Acta Biomater. 4, 273 (2008).

[13] J. Rawat, S. Rana, M.M. Sorensson, R.D.K. Misra, Mater. Sci. Technol. 23, 97 (2007).

[14] Z. Klencsár, Gy. Tolnai, L. Korecz, I. Sajó, P. Németh, J. Osán, S. Mészáros, E. Kuzmann, Solid State Sci. 24, 90 (2013).

[15] O. Yalçın, H. Bayrakdar, S. Özüm, J. Magn. Magn. Mater. 343, 157 (2013) and references therein.

[16] H. Bayrakdar, O. Yalçın, S. Vural, K. Esmer, J. Magn. Magn. Mater. 343, 86 (2013) and references therein.

[17] B.F. Bogacz, R. Gargula, P. Kurzydło, A.T. Pędziwiatr, T. Tatarchuk, N. Paliychuk, Acta Phys. Pol. A 134, 993 (2018).

[18] N. Danyliuk, J. Tomaszewska, T. Tatarchuk, J. Mol. Liq. 309, 113077 (2020).

[19] T. Tatarchuk, A. Shyichuk, J. Lamkiewicz, J. Kowalik, Ceram. Int. 46, 14674 (2020).

[20] T. Tatarchuk, Mu. Naushad, J. Tomaszewska, P. Kosobucki, M. Myslin, H. Vasylyeva, P. Ścigalski, Environ. Sci. Pollut. Res. 27, 26681 (2020). 
[21] T. Tatarchuk, A. Shyichuk, I. Trawczyńska, I. Yaremiy, A.T. Pędziwiatr, P. Kurzydło, B.F. Bogacz, R. Gargula, Ceram. Int., 27517 (2020)10.1016/j.ceramint.2020.07.243.

[22] P. Vlazan, I. Miron, P. Sfirloaga, Ceram. Int. 41, 3760 (2015).

[23] A.C. Lima, A.P.S. Peres, J.H. Araújo, M.A. Morales, S.N. Medeiros, J.M. Soares, D.M.A. Melo, A.S. Carriço, Mater. Lett. 145, 56 (2015).

[24] M.A. Khan, S. Riaz, I. Ali, M.N. Akhtar, G. Murtaza, M. Ahmad, I. Shakir, M.F. Warsi, Ceram. Int. 41, 651 (2015).

[25] B.B. Zhang, J.C. Xu, P.H. Xin et al., J. Solid State Chem. 221, 302 (2015).

[26] C. Singh, S. Bansal, V. Kumar, S. Singhal, Ceram. Int. 41, 3595 (2015).

[27] S. Dabagh, A.A. Ati, R.M. Rosnan, S. Zare, Z. Othaman, Mater. Sci. Semicond. Process. 33, 1 (2015).

[28] N. Kumari, V. Kumar, S. Khasa, S.K. Singh, Ceram. Int. 41, 1907 (2015).

[29] V.S. Sawant, K.Y. Rajpure, J. Magn. Magn. Mater. 382, 152 (2015).

[30] S.S. Thakur, A. Pathania, P. Thakur, A. Thakur, J.-H. Hsu, Ceram. Int. 41, 5072 (2015).

[31] Z. Tian, C. Zhu, J. Wang, Z. Xia, Y. Liu, S. Yuan, J. Magn. Magn. Mater. 377, 176 (2015).

[32] R.K. Panda, R. Muduli, D. Behera, J. Alloys Compd. 634, 239 (2015).

[33] Z. Kaiwen, Q. Liqin, W. Xuehang, W. Wenwei, S. Yuexiao, T. Yulin, L. Jieyue, Ceram. Int. 41, 1235 (2015).

[34] W.B. Dlamini, J.Z. Msomi, T. Moyo, J. Magn. Magn. Mater. 373, 78 (2015).

[35] S. Thakur, R. Rai, S. Sharma, Mater. Lett. 139, 368 (2015).

[36] S. Kumar, V. Singh, U.K. Mandal, R.K. Kotnala, Inorg. Chim. Acta 428, 21 (2015).

[37] U.B. Sontu, V. Yelasani, V.R.R. Musugu, J. Magn. Magn. Mater. 374, 376 (2015).

[38] M. Gharagozlou, R. Bayati, Superlattices Microstruct. 78, 190 (2015).

[39] S.-F. Wang, Y.-F. Hsu, K.-M. Chou, J.-T. Tsai, J. Magn. Magn. Mater. 374, 402 (2015).

[40] S. Chakrabarty, A. Dutta, M. Pal, J. Alloys Compd. 625, 216 (2015).

[41] S.I. Hussein, A.S. Elkady, M.M. Rashad, A.G. Mostafa, R.M. Megahid, J. Magn. Magn. Mater. 379, 9 (2015).
[42] P.P. Hankare, A.S. Tapase, R.S. Pandav, K.M. Garadkar, I.S. Mulla, Mater. Sci. Semicond. Process. 31, 439 (2015).

[43] S. Kumar, P. Kumar, V. Singh, U.K. Mandal, R.K. Kotnala, J. Magn. Magn. Mater. 379, 50 (2015).

[44] L. Wang, B.K. Rai, S.R. Mishra, Mater. Res. Bull. 65, 183 (2015).

[45] Ch.V. Reddy, C. Byon, B. Narendra, D. Baskar, G. Srinivas, J. Shim, S.V.P. Vattikuti, Superlattices Microstruct. 82, 165 (2015).

[46] B. Kalska-Szostko, D. Satuła, W. Olszewski, Curr. Appl Phys. 15, 226 (2015).

[47] R.S. Yadav, J. Havlica, M. Hnatko et al., J. Magn. Magn. Mater. 378, 190 (2015).

[48] D. Kotsikau, M. Ivanovskaya, V. Pankov, Y. Fedotova, Solid State Sci. 39, 69 (2015).

[49] R. Saez Puche, M.J. Torralvo Fernandez, V. Blanco Gutierrez, R. Gomez, V. Marquina, M.L. Marquina, J.L. Perez Mazariego, R. Ridaura, Bol. Soc. Esp. Ceram. 47, 133 (2008).

[50] H. Bayrakdar, O. Yalçın, U. Cengiz, S. Özüm, E. Anigi, O. Topel, Spectrosc. Acta A Mol. Biomol. Spec. 132, 160 (2014).

[51] H. Bayrakdar, J. Magn. Magn. Mater. 323, 1882 (2011).

[52] H. Bayrakdar, PIER M. 25, 269 (2012).

[53] M. Sajjia, K.Y. Benyounis, A.G. Olabi, Powder Technol. 222, 143 (2012).

[54] B.P. Jacob, A. Kumar, R.P. Pant, S. Singh, E.M. Mohammed, Bull. Mater. Sci. 34, 1345 (2011).

[55] R.D.K. Misra, S. Gubbala, A. Kale, W.F. Egelhoff Jr., Mater. Sci. Eng. B 111, 164 (2004).

[56] A.J. Rondinone, Chao Liu, Z. John Zhang, J. Phys. Chem. B 105, 7967 (2001).

[57] C. Liu, B. Zou, A.J. Rondinone, Z.J. Zhang, J. Am. Chem. Soc. 122, 6263 (2000).

[58] R. Masrour, O. Mounkachi, H. El Moussaoui, M. Hamedoun, A. Benyoussef, E.K. Hlil, M. Ben Ali, K. El Maalam, J. Supercond. Nov. Magn. 26, 3443 (2013).

[59] A.A. Ati, Z. Othaman, A. Samavati, J. Mol. Struct. 1052, 177 (2013).

[60] R.K. Singh, A. Narayan, K. Prasad, R.S. Yadav, A.C. Pandey, A.K. Singh, L. Verma, R.K. Verma, J. Therm. Anal. Calorim. 110, 573 (2012).

[61] J. Wang, F. Ren, R. Yi, A. Yan, G. Qiu, X. Liu, J. Alloys Comp. 479, 791 (2009). 
[62] K.V.P.M. Shafi, Y. Koltypin, A. Gedanken, R. Prozorov, J. Balogh, J. Lendvai, I. Felner, J. Phys. Chem. B 101, 6409 (1997).

[63] Y.M.Z. Ahmed, Ceram. Int. 36, 969 (2010).

[64] M. Atif, S.K. Hasanian, M. Nadeem, Solid State Commun. 138, 416 (2006).

[65] Advances in Crystallization Processes, Ed. Y. Mastai, InTech, 2012.

[66] Y.I. Kim, D. Kim, C.S. Lee, Physica B 337, 42 (2003).

[67] C. Caizer, M. Popovici, C. Savii, Acta Mater. 51, 3607 (2003).

[68] D.K. Kim, Y. Zhang, W. Voit, K.V. Rao, M. Muhammed, J. Magn. Magn. Mater. 225, 30 (2001).

[69] J.A.L. Pérez, M.A.L. Quintela, J. Mira, J. Rivas, S.W. Charles, J. Phys. Chem. B 101, 8045 (1997).

[70] Q. Chen, Z.J. Zhang, Appl. Phys. Lett. 73, 3156 (1998).

[71] Z.X. Tang, C.M. Sorensen, K.J. Klabunde, G.C. Hadjipanayis, J. Coll. Interface Sci. 146, 38 (1991).

[72] C.T. Seip, E.E. Carpenter, C.J. O'Connor, V.T. John, S. Li, IEEE Trans. Magn. 34, 1111 (1998).

[73] J.F. Hochepied, P. Bonville, M.P. Pileni, J. Phys. Chem. B 104, 905 (2000).

[74] C. Liu, B. Zou, A.J. Rondinone, Z.J. Zhang, J. Phys. Chem. B 104, 1141 (2000).

[75] K. Klopfer, U. Niedermayer, H. Klingbeil, W. Ackermann, H.G. König, T. Weiland, Phys. Rev. ST Accel. Beams 18, 010101 (2015).

[76] D.S. Mathew, R.-S. Juang, Chem. Eng. J. 129, 51 (2007).

[77] See for general reviews: Spin Crossover in Transition Metal Compounds I-III, Topics in Current Chemistry book series, Vol. 233, (2004).
[78] T. Forestier, A. Kaiba, S. Pechev, D. Denux, P. Guionneau, C. Etrillard, N. Daro, E. Freysz, J.-F. Létard, Chem. Eur. J. 15, $6122(2009)$.

[79] T. Forestier, S. Mornet, N. Daro, T. Nishihara, S.-I. Mouri, K. Tanaka, O. Fouché, E. Freysz, J.-F. Létard, Chem. Commun. 36, 4327 (2008).

[80] D. Zabetakis, M. Dinderman, P. Schoen, Adv. Mater. 17, 734 (2005).

[81] J.B. Da Silva, N.D.S. Mohallem, J. Magn. Magn. Mater. 226-230, 1393 (2001).

[82] K.I. Arshak, A. Ajina, D. Egan, Microelectron. J. 32, 113 (2001).

[83] Y. Hwang, Mater Lett. 60, 3277 (2006).

[84] Y. Naito, K. Suetake, IEEE Trans. Microw. Theory Techn. 19, 65 (1971).

[85] R.C. Che, C.Y. Zhi, C.Y. Liang, X.G. Zhou, Appl. Phys. Lett. 88, 033105 (2006).

[86] S. Sutradhar, S. Das, A. Roychowdhury, D. Das, P.K. Chakrabarti, Mater. Sci. Eng. B 196, 44 (2015).

[87] A. Ghasemi, S.E. Shirsath, X. Liu, A. Morisako, J. Appl. Phys. 109, 07A507 (2011).

[88] A. Ghasemi, J. Magn. Magn. Mater. 330, 163 (2013).

[89] J.M.D. Coey, Rare Earth Permanent Magnetism, Wiley, New York 1996, p. 220.

[90] R.C. Kambale, K.M. Song, Y.S. Koo, N. Hur, J. Appl. Phys. 110, 053910 (2011).

[91] Z.L. Wang, Y. Liu, Z. Zhang, Handbook of Nanophase and Nanostructured Materials, Materials Systems and Applications I, Vol. III, Kluwer, USA 2003. 